\title{
Partial Nucleotide Sequence and Genome Organization of a Canadian Isolate of Little cherry virus and Development of an Enzyme-Linked Immunosorbent Assay-Based Diagnostic Test
}

\author{
J. Theilmann, J. Mozafari, R. Reade, Z. Wu, W. Xie, \\ G. Jesperson, M. Bernardy, K. C. Eastwell, and D. Rochon
}

First, second, third, fourth, fifth, seventh, and ninth authors: Agriculture and Agri-Food Canada, Pacific Agri-Food Research Centre, Summerland, B.C. V0H 1Z0; sixth author: British Columbia Ministry of Agriculture, Food and Fisheries, 200-1690 Powick Road, Kelowna, B.C. V1X 7G5; and eighth author: Washington State University-IAREC, 24106 N. Bunn Road, Prosser 99350. Current address of Z. Wu: Citrus Research and Education Center, University of Florida, Lake Alfred 33850. Accepted for publication 5 October 2001.

\begin{abstract}
Theilmann, J., Mozafari, J., Reade, R., Wu, Z., Xie, W., Jesperson, G., Bernardy, M., Eastwell, K. C., and Rochon, D. 2002. Partial nucleotide sequence and genome organization of a Canadian isolate of Little cherry virus and development of an enzyme-linked immunosorbent assay-based diagnostic test. Phytopathology 92:87-98.

Approximately $12.4 \mathrm{~kb}$ of the genome of a mealybug-transmissible, North American isolate of Little cherry virus (LChV-3, previously designated LChV-LC5) has been cloned and sequenced. The sequenced portion of the genome contains 10 open reading frames (ORFs) and, based on sequence comparisons, encodes a putative RNA helicase (HEL), RNA-dependent RNA polymerase (POL), two coat proteins (CPs), a homologue of HSP70, a 53K protein (p53) that is similar to an equivalent-size protein in other closteroviruses, and a $22 \mathrm{~K}$ (p22) protein

of unknown function. The genome also potentially encodes two small proteins (p5 and p6), one of which is similar to the small hydrophobic proteins of other closteroviruses. Phylogenetic analyses utilizing sequences of the HEL, POL, and HSP70 homologue suggest that LChV-3 is most similar to other mealybug-transmitted closteroviruses. Further comparisons between $\mathrm{LChV}-3$ and a $4.7-\mathrm{kb}$ region of the recently described Little cherry virus-2 (LChV-2) reveals $77 \%$ nucleotide sequence identity. Based on this low sequence identity, we propose that LChV-3 be considered a separate species, designated LChV-3. Unexpectedly, the LChV-3 CP duplicate ORF was found to lie upstream of the HSP70 ORF; therefore, the genome organization of LChV-3 is distinct from that of other closteroviruses. Polyclonal antiserum raised to bacterially expressed LChV-3 CP was useful for detection of LChV-diseased trees in the cherry-growing districts of British Columbia, Canada.
\end{abstract}

Little cherry disease (LChD) occurs in several cultivars of sweet cherry resulting in small fruit with poor color. Affected cherries also fail to develop significant sweetness and acidity, rendering cherries unmarketable (42). LChD was first identified in 1933 in the Kootenay Valley of British Columbia, Canada (39). The disease spread quickly, affecting virtually all orchards and all of the trees within these orchards. Production declined by $90 \%$ between 1947 and 1979, by which time most fruit was not marketable. LChD remains a threat to the cherry industry in British Columbia $(8,17)$ and measures to control spread of the disease are in place. Detection and diagnosis of the causative agent of $\mathrm{LChD}$ represents a major part of $\mathrm{LChD}$ control. Subsequent to its first recorded outbreak in Canada, $\mathrm{LChD}$ has been found worldwide (41). A serious outbreak of LChD has recently been recorded in northern Germany (36).

The apple mealybug (Phenacoccus aceris Signoret) has been identified as a vector for $\mathrm{LChD}$ (34). Transmission of $\mathrm{LChD}$ can also occur by grafting or budding (13). Several studies suggest the partial or sole involvement of a virus in $\operatorname{LChD}(5,7)$. Moreover, the cloning and sequencing of an approximately $0.5-\mathrm{kb}$ segment of the double-stranded (ds)RNA associated with LChD has been reported, and nucleotide sequence comparisons indicate that the dsRNA is derived from the single-stranded (ss)RNA genome of a closterovirus (previously designated Little cherry

Corresponding author: D. Rochon; E-mail address: rochonda@em.agr.ca

Publication no. P-2001-1113-01R

For the Department of Agriculture and Agri-Food, Government of Canada.

(C) Minister of Public Works and Government Services Canada 2002 virus [LChV]-LC5 but identical to LChV-3 described here) that is phylogenetically related to other mealybug-transmitted closteroviruses (6). In addition, a virus originally obtained from the United States and associated with LChD in Germany (LChV-2) has been partially characterized. Limited sequence comparisons suggest that LChV-2 is similar to LChV-3 (36) and phylogenetic analyses using amino acid sequences of the putative polymerase (POL) and helicase (HEL) proteins indicate a close relationship between LChV-2 and other mealybug-transmitted closteroviruses (36).

The complete genomic nucleotide sequence of another virus (LChV-1) also associated with LChD in Germany has been reported (16). Phylogenetic analyses indicate that LChV-1 is a remote member of the "whitefly" lineage of closteroviruses $(16,22)$. Sequence comparisons indicate that only a distant relationship exists between LChV-1 and the sequenced portions of either LChV-2 or LChV-3 $(6,36)$.

Here we report the sequence of a 12.4-kb segment of the LChV3 genome. Phylogenetic comparisons indicate a close relationship between LChV-3 and other closteroviruses known or believed to be mealybug transmitted. In addition, limited sequence identity (77\% overall) exists between sequenced portions of the $\mathrm{LChV}-3$ genome and that of LChV-2, suggesting that LChV-3 is a distinct virus. Sequence analysis shows that the LChV-3 genome organization is distinct from that of other closteroviruses in that one coat protein $(\mathrm{CP})$ open reading frame $(\mathrm{ORF})$ is located $5^{\prime}$ to the HSP70 homologue ORF. Polyclonal antisera raised to bacterially expressed CP were prepared and shown to be useful in a survey to identify LChV-3 in cherry trees in British Columbia, Canada. 


\section{MATERIALS AND METHODS}

Virus source and purification of dsRNA. dsRNA was extracted from a stock cherry tree (A40-17) infected with the LC5 isolate of $\mathrm{LChV}(\mathrm{LChV}-3 ;$ ) as described by Eastwell and Bernardy (5). This isolate (previously designated LChV-LC5) (6) was established by mealybug transmission to Prunus avium 'Lambert' trees from a commercial orchard in the Okanagan Valley of British Columbia, Canada (5).

Purification of LChV-3 virions. This procedure was modified from a large-scale procedure described by Eastwell and Bernardy (6). Two LChV-3-infected cherry leaves were ground to a fine powder in liquid nitrogen with a mortar and pestle. Cold extraction buffer $\left(20 \mathrm{ml}\right.$, consisting of $25 \mathrm{mM} \mathrm{Na} \mathrm{HPO}_{4}, 25 \mathrm{mM}$ $\mathrm{KH}_{2} \mathrm{PO}_{4}, 1 \%$ Triton-X $100,0.5 \%$ skim milk powder, and $0.3 \% \beta$ mercaptoethanol) was added and the slurry was allowed to stand at $4^{\circ} \mathrm{C}$ for $30 \mathrm{~min}$ before filtering through one layer of Miracloth (Calbiochem, Edmonton, Alberta). The filtrate was centrifuged for $15 \mathrm{~min}$ at $6,000 \times \mathrm{g}$. The supernatant was adjusted to $15 \%$ chloroform, stirred at room temperature for $15 \mathrm{~min}$, then centrifuged at $8,000 \times g$ for $15 \mathrm{~min}$ at room temperature. The aqueous phase was adjusted to $0.2 \mathrm{M} \mathrm{NaCl}$ and $5 \%(\mathrm{wt} / \mathrm{vol}$ ) polyethylene glycol 8000 (Sigma, Oakville, Ontario), stirred for $2 \mathrm{~h}$ at $4^{\circ} \mathrm{C}$, then centrifuged for $20 \mathrm{~min}$ at $12,000 \times \mathrm{g}$. The pellet was resuspended in $1 \mathrm{ml}$ of

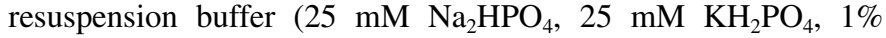
Triton-X 100, and $0.16 \% \beta$-mercaptoethanol) overnight at $4^{\circ} \mathrm{C}$ and centrifuged at $14,000 \times g$ for $5 \mathrm{~min}$ in a microfuge. The supernatant was removed, adjusted to $4 \mathrm{ml}$ with resuspension buffer, and centrifuged in a Beckman SW60 for $2 \mathrm{~h}$ at $45,000 \mathrm{rpm}$ at $4^{\circ} \mathrm{C}$. The pellet was resuspended in $10 \mathrm{mM}$ sodium borate, $\mathrm{pH} 7.8$, and stored at $4^{\circ} \mathrm{C}$.

Cloning and sequencing of the LChV-3 CP genes. dsRNA purified as described by Eastwell and Bernardy (5) was used as a template for cloning and sequencing of the LChV-3 genome. The dsRNA template was denatured prior to reverse transcription using $12 \mathrm{mM}$ methyl mercuric hydroxide. Primers (Table 1) corresponding to the $5^{\prime}$ or $3^{\prime}$ regions of a previously sequenced approximately 500-nt portion of the LChV-3 POL ORF (6) were used to synthesize cDNA extending toward the $5^{\prime}$ or $3^{\prime}$ ends of the genome, respectively. cDNA was then tailed, with either poly(A) or poly $(\mathrm{G})$, using terminal transferase (Gibco/BRL, Burlington, Ontario). The A- or G-tailed cDNA was then amplified by polymerase chain reaction (PCR) using either oligo $\mathrm{dT}_{-(12-18)}$ or oligo $\mathrm{dC}_{-(12-18)}$ primers and an oligonucleotide complementary to the primer used in the first-strand cDNA reaction. Reverse transcriptase (RT)-PCR products were cloned and sequenced. Subsequent cloning proceeded as above using oligonucleotide primers (Table 1) corresponding to the $5^{\prime}$ or $3^{\prime}$ ends of the newly cloned fragments. RT-PCR products were cloned into either pGEM-T (Pro-

TABLE 1. Primers used for cloning of Little cherry virus-3 genomic sequences

\begin{tabular}{llc}
\hline $\begin{array}{l}\text { Primer } \\
\text { name }\end{array}$ & \multicolumn{1}{c}{ Primer sequence $\left(5^{\prime}-3^{\prime}\right)$} & Genome location \\
\hline A106(-) & CAATGCGCACAAGACTTGC & $347-329$ \\
A47(-) & CACAACCACCATACTGTCTTC & $1,093-1,073$ \\
A9(-) & CTCCACAGTCGGTAAATCCC & $1,882-1,863$ \\
A5(-) & ATACAGACAGTGTCGCACCT & $2,664-2,645$ \\
LCV9(+) & CTTGTACTCCATGCTTGCTC & $4,872-4,891$ \\
A12(+) & CACAGAGTGACTAACGGTCACA & $5,660-5,681$ \\
A24(+) & CATTGACGCGGCTATCGCT & $7,889-7,907$ \\
A33(+) & CTACGTACGACGACATTCTGTC & $9,600-9,621$ \\
A36(+) & GGCTTATAACTGAGATAGACGAG & $10,649-10,671$ \\
A43(+) & GTACACTGGTTAACTAGTGG & $11,737-11,756$ \\
Wu6(-) & TCAACACCCAAGCGACGAAGTACC & $4,240-4,217$ \\
Wu5(+) & GACGATGTTGTTTGTCTCCTGG & $4,704-4,725$ \\
\hline
\end{tabular}

${ }^{a}$ Signs following primer names indicate whether the primer corresponds to the sense (+) or the antisense (-) of the genome. mega, Ottawa, Ontario) or pT7Blue (Novagen, Madison, WI). Cloned cDNA was sequenced by cycle sequencing using dyelabeled terminators and AmpliTaq Polymerase, FS (Perkin-Elmer, Mississauga, Ontario). Samples were sequenced using an ABI PRISM 310 Genetic Analyzer. The sequence was subsequently verified utilizing total ssRNA extracted from infected cherry leaves using Qiagen RNeasy columns (Qiagen Canada, Mississauga, Ontario) and pairs of primers synthesized to independent regions of the previously obtained overlapping cDNA clones.

Sequence analysis. HEL, POL, and HSP70 homologue sequences were aligned using ClustalW or programs available through the Genetics Computer Group (3). Amino acid sequence alignments of CPs were conducted using an algorithm similar to FASTA (30) and available through GeneWorks (IntelliGenetics, Inc., Mountain View, CA). Generation of consensus phylogenetic trees were as follows. Aligned sequences were subjected to resampling using the bootstrap method (11) and 100 replicates. A consensus phylogenetic tree was obtained using a Web-based version of the program Phylip (WebPhylip) originally described by Felsenstein (PHYLIP 3.2 manual; University of California Herbarium, Berkeley) and available through the Canadian Bioinformatics Resource. The Fitch-Margoliash (12) or Neighbor-joining method (37) was used to construct the phylogenies.

Expression and purification of $\mathrm{LChV}-3 \mathrm{CPs}$ in $\boldsymbol{E}$. coli. The LChV-3 p39 ORF8 was cloned into the expression vector pET-21d (Novagen) as follows. Primers A59 (5'ACCATGGCAGATTCATCTATAACG3') and A60 (5'ACTCGAGACATAATTTCTCAAGTACACTC3') were used to RT-PCR amplify the complete p39 ORF (1,079 nt) from RNeasy (Qiagen) purified ssRNA from LChV-3-infected cherry leaves. Primer A59, the plus-sense primer, corresponds to the $5^{\prime}$ terminus of the p39 ORF (the ATG start codon is in bold), and contains an added NcoI restriction enzyme site (underlined). Primer A60, the minus sense primer, corresponds to the $3^{\prime}$ terminus and contains an added XhoI restriction enzyme site (underlined). It also contains a substitution (in bold type) to eliminate the p39 stop codon. The RT-PCR product was ligated into pGEM-T, digested with NcoI and XhoI, and cloned into the corresponding site of pET-21d upstream of the sequence encoding the polyhistidine tag. pLys $\mathrm{S}$ cells (Novagen) were transformed and expression induced by the addition of isopropyl- $\beta$-D-thiogalactopyranoside to $1 \mathrm{mM}$. Pelleted cells were resuspended in native extraction buffer $(50 \mathrm{mM}$ sodium phosphate buffer, pH 7.0, containing $300 \mathrm{mM}$ sodium chloride), lysed, then centrifuged at $12,000 \times g$ for $20 \mathrm{~min}$ at $4^{\circ} \mathrm{C}$. Pelleted protein was resuspended in denaturing extraction buffer (native buffer containing $6 \mathrm{M}$ guanidine $\mathrm{HCl}$ ) and then centrifuged at $12,000 \times g$ for $20 \mathrm{~min}$ at $4^{\circ} \mathrm{C}$ to remove cell debris. Polyhistidine-tagged (His-tagged) p39 protein was then purified by cobalt-chelate chromatography using Talon Metal Affinity Resin (Clontech, Palo Alto, CA) following the manufacturer's recommendations. Protein from the bound fraction was dialyzed successively against extraction buffer containing decreasing concentrations of guanidine $\mathrm{HCl}(5.4,4,3,2,1$, and $0 \mathrm{M})$. Protein was concentrated using a Centricon centrifugal filter (Millipore, Amicon Canada, Oakville, Ontario).

A similar strategy was used in attempts to produce His-tagged LChV-3 p55 (ORF3) protein in E. coli but was not successful in producing enough pure protein. The p55 protein ORF was therefore fused with the maltose-binding protein ORF in the pMAL-c2 vector (New England BioLabs, Inc., Mississauga, Ontario) following cloning in pET21-d as follows. Primers A63 (5'TTCGAATTCATGACTTCTGCACAAATGACAGAC3') and A64 (5'ACCAAGCTTGCTTTGTTAGCAGCCGGATC3') were used to PCR assay the $\mathrm{p} 55 \mathrm{ORF}$ from the pET21-d construct to produce a construct in which the p55 ORF was fused to the C-terminus of the maltose-binding protein in pMAL-c2 (New England Biolabs, Inc.). Primer A63 corresponds to the $5^{\prime}$ end of the ORF and includes an added EcoRI site (underlined) for cloning purposes. 
Primer A64 corresponds to sequences entirely in pET21-d downstream of the His-tag and contains a HindIII site for cloning. The PCR product was cloned into EcoRI/HindIII-digested pMAL-c2. Purification of the p55 fusion protein from transformed DH5 $\alpha$ cells utilized affinity chromatography on amylose resin as suggested by the manufacturer (New England BioLabs, Inc.).

Production of antisera. Antibodies were raised to expressed p55 or p39 by injecting 500 to $750 \mu \mathrm{g}$ of purified protein into female New Zealand white rabbits. Freund's complete adjuvant was used for the first injection; in all subsequent injections, Freund's incomplete adjuvant was used. The protein was injected a total of four times at 2-week intervals and blood samples taken following the fourth injection were used for immunoglobulin $G$ (IgG) purification.

Western blot analysis. From 10 leaves collected from each cherry tree and stacked, $0.2 \mathrm{~g}$ of leaf tissue was torn. The leaf tissue was ground in a bevel roller tissue grinder and eluted with $2 \mathrm{ml}$ of extraction buffer $(0.5 \mathrm{M}$ Tris $\mathrm{pH} 8.2,140 \mathrm{mM} \mathrm{NaCl}, 2 \%$ PVP-40, $1 \%$ PEG 6000, and $0.05 \%$ Tween 20). Leaf extracts were clarified by low-speed centrifugation and $16 \mu$ lof the supernatant was mixed with $4 \mu \mathrm{l}$ of $5 \times$ Laemmli sample buffer $(1 \times$ Laemmli buffer is $62.5 \mathrm{mM}$ Tris- $\mathrm{HCl}, \mathrm{pH} 6.8,2 \%$ sodium dodecyl sulfate [SDS], $0.7 \mathrm{M} \beta$-mercaptoethanol, and $10 \%$ glycerol). Proteins were separated on $12 \%$ polyacrylamide gels containing SDS, according to Laemmli (26), along with Benchmark Prestained Protein Ladder (Gibco/BRL, Burlington, Ontario). Proteins were transferred to polyvinylidene diflouride membranes (BioRad Laboratories, Mississauga, Ontario). IgG was diluted 1:1,000 and detected using the ECL system (Amersham/Pharmacia Biotech, Baie D'urfee, Quebec).

Enzyme-linked immunosorbent assay analysis. Doubleantibody sandwich enzyme-linked immunosorbent assay (DASELISA) was performed using a modification of the procedure described by Clark and Adams (2). Wells of 96-well microtiter plates (Linbro; ICN Biomedicals Inc., Horsham, PA) were coated with $0.5 \mu \mathrm{g}$ of IgG diluted to $100 \mu \mathrm{l}$ in coating buffer $(15 \mathrm{mM}$ $\mathrm{Na}_{2} \mathrm{CO}_{3}$ and $35 \mathrm{mM} \mathrm{NaHCO}, \mathrm{pH}$ 9.6) and incubated for $3 \mathrm{~h}$ at $37^{\circ} \mathrm{C}$. Plates were washed extensively with distilled water and blocked with $200 \mu \mathrm{l}$ of $2 \%$ skim milk in phosphate-buffered saline
(PBS) for $30 \mathrm{~min}$ at $37^{\circ} \mathrm{C}$. Blocking solution was removed and $100 \mu \mathrm{l}$ of undiluted leaf sap, prepared as described above for western blot analysis, was added to wells and incubated overnight at $4{ }^{\circ} \mathrm{C}$. Plates were washed and anti-LChV-3 p39 IgG conjugated to biotin (using the ECL Protein Biotinylation Kit; Amersham/ Pharmacia Biotech) was added at a dilution of $1: 1,000$ in $0.2 \%$ skim milk-PBS and incubated for $1 \mathrm{~h}$ at $37^{\circ} \mathrm{C}$. Plates were washed and alkaline phosphatase conjugated streptavidin (i.e., 0.2 units $/ \mathrm{ml}$; Roche Molecular Biochemicals, Laval, Quebec) was added at a dilution of 1:5,000 in 0.2\% skim milk-PBS and incubated for $1 \mathrm{~h}$ at $37^{\circ} \mathrm{C}$. The plates were washed and substrate $(5 \mathrm{mg}$ of $p$-nitrophenyl phosphate substrate [Sigma 104] in $5 \mathrm{ml}$ of $100 \mathrm{mM}$ Tris, $\mathrm{pH} 9.5,100 \mathrm{mM} \mathrm{NaCl}$, and $5 \mathrm{mM} \mathrm{MgCl}_{2}$ ) was added. Plates were incubated at $37^{\circ} \mathrm{C}$ for $30 \mathrm{~min}$ to $3 \mathrm{~h}$. The color reaction was monitored by measuring absorbance at $405 \mathrm{~nm}$ using a Dynatech MRX ELISA plate reader (VWR Canlab, Mississauga, Ontario).

\section{RESULTS}

Cloning and sequencing strategy. The sequence of a previously described cDNA clone (pSLD126) (6) corresponding to the POL region of LChV-3 was used to generate additional overlapping clones toward the $5^{\prime}$ and $3^{\prime}$ ends of the genome. Several clones corresponding to approximately $4.5 \mathrm{~kb}$ upstream and $7.3 \mathrm{~kb}$ downstream from this clone were obtained. A representative subset of clones spanning this region is shown in Figure 1B. The individual clones were fully sequenced and then the entire sequence was verified by sequencing RT-PCR products or clones of RT-PCR products obtained utilizing primers specific to independent overlapping clones (Fig. 1C). The sequence has been deposited in GenBank (Accession No. AF416335). The organization of the cloned portion of the LChV-3 genome as determined from the sequence is shown in Figure 1A.

Genome structure and function of $\mathrm{LChV}-3$ encoded proteins. ORF 1a. ORF1a extends from the beginning of the cloned region to a TAA termination codon at nucleotide 3338 (predicted molecular weight is 122,816 ). The $3^{\prime}$ region of ORF1a encodes amino acid sequences with similarity to each of the six motifs of known and putative HELs (25). It is 93\% identical to the HEL

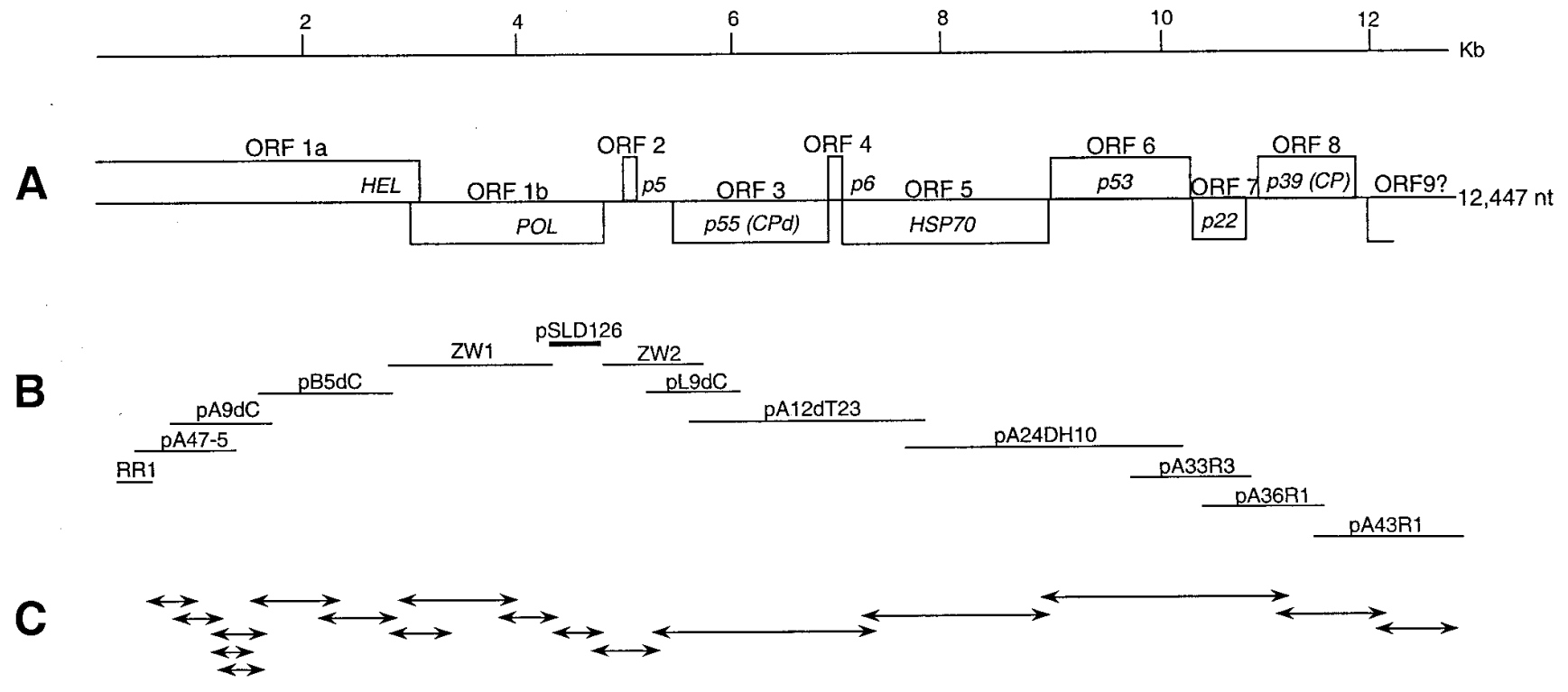

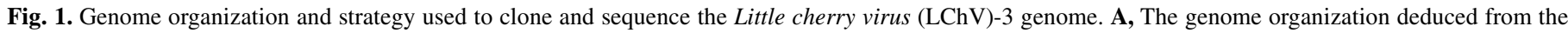

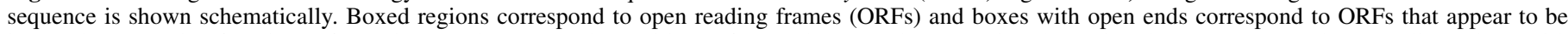

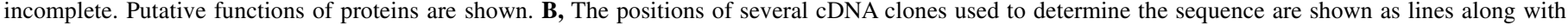

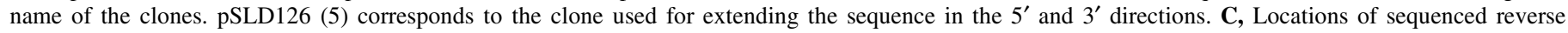

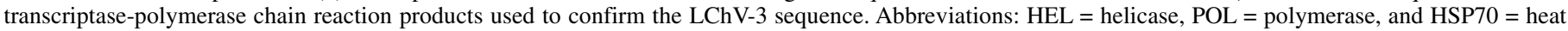
shock protein 70 -like proteins; $\mathrm{CP}=$ coat protein, $\mathrm{CPd}=\mathrm{CP}$ duplicate. 
region of a recently described $\mathrm{LChV}-2$ isolate (36) (Fig. 2A). ORF1a is likely incomplete because it does not encode the methyltransferase and papain-like protease motifs found in other closteroviruses (4).

ORF1b. ORF1b begins at an ATG codon at nucleotide 3324 just prior to the termination of ORF1a. The protein product of this ORF has a predicted molecular weight of 58,834 and contains the GDD motif and eight conserved sequence motifs found in known and putative RNA-dependent RNA POLs of most RNA viruses (25). Sequence comparisons show $94 \%$ identity to the POL region of LChV-2 (Fig. 2B). Expression of ORF1b in other closteroviruses (31) has been shown to occur via +1 ribosomal frameshifting. This mode of expression may also occur in LChV-3 but the existence of a potential initiator codon at nucleotide 3324 suggests that frameshifting may not be required. For example, expression of ORF1b may occur via a subgenomic mRNA that encompasses ORF1b.

ORF2. A 280-nt intercistronic region separates ORF2 from ORF1b. ORF2 potentially encodes a 51-amino acid polypeptide with a calculated molecular weight of 5,411 (p5). No significant amino acid sequence similarity was found between this protein and proteins present in the databases.

ORF3. A 232-nt intercistronic region separates ORF2 from ORF3. ORF3 initiates at nucleotide 5540 and has the potential to encode a protein with a calculated molecular weight of 55,399 (p55). Analysis of this sequence revealed significant amino acid sequence similarity to the CPs and CP duplicates (CPds) of several closteroviruses (Fig. 3). Further evidence that the p55 protein represents a LChV-3 CP will be described below.

ORF4. ORF4 initiates at nucleotide 7009 and has the potential to encode a protein of molecular weight 6,177 (p6). The amino terminal region of $\mathrm{p} 6$ contains a high proportion of hydrophobic amino acids and is similar in sequence to p5 of Pineapple mealybug wilt associated virus-2 (PMWaV-2) (31) (i.e., the first 28 amino acids of PMWaV-2 shares 10 amino acid positions in common with the amino-terminal region of LChV-3; data not shown). Similar-sized hydrophobic proteins suggested to be membranebinding proteins are present in other closteroviruses (4), but significant sequence similarity with these proteins was not found.

ORF5. ORF5 initiates at nucleotide 7176 just prior to the termination codon of ORF4. The predicted protein product has a calculated molecular weight of 59,967 (p60). Database searches revealed strong similarity to the HSP70 homologues of other closteroviruses. An alignment of p60 with the HSP70 homologues of several selected closteroviruses is shown in Figure 4. LChV-3 p60 contains the eight conserved motifs (A through $\mathrm{H}$ ) present in cellular HSP70 proteins (4).

ORF6. The start codon of ORF6 begins three nucleotides downstream of the ORF5 stop codon and has the potential to encode a protein of 53,367 molecular weight (p53). Database

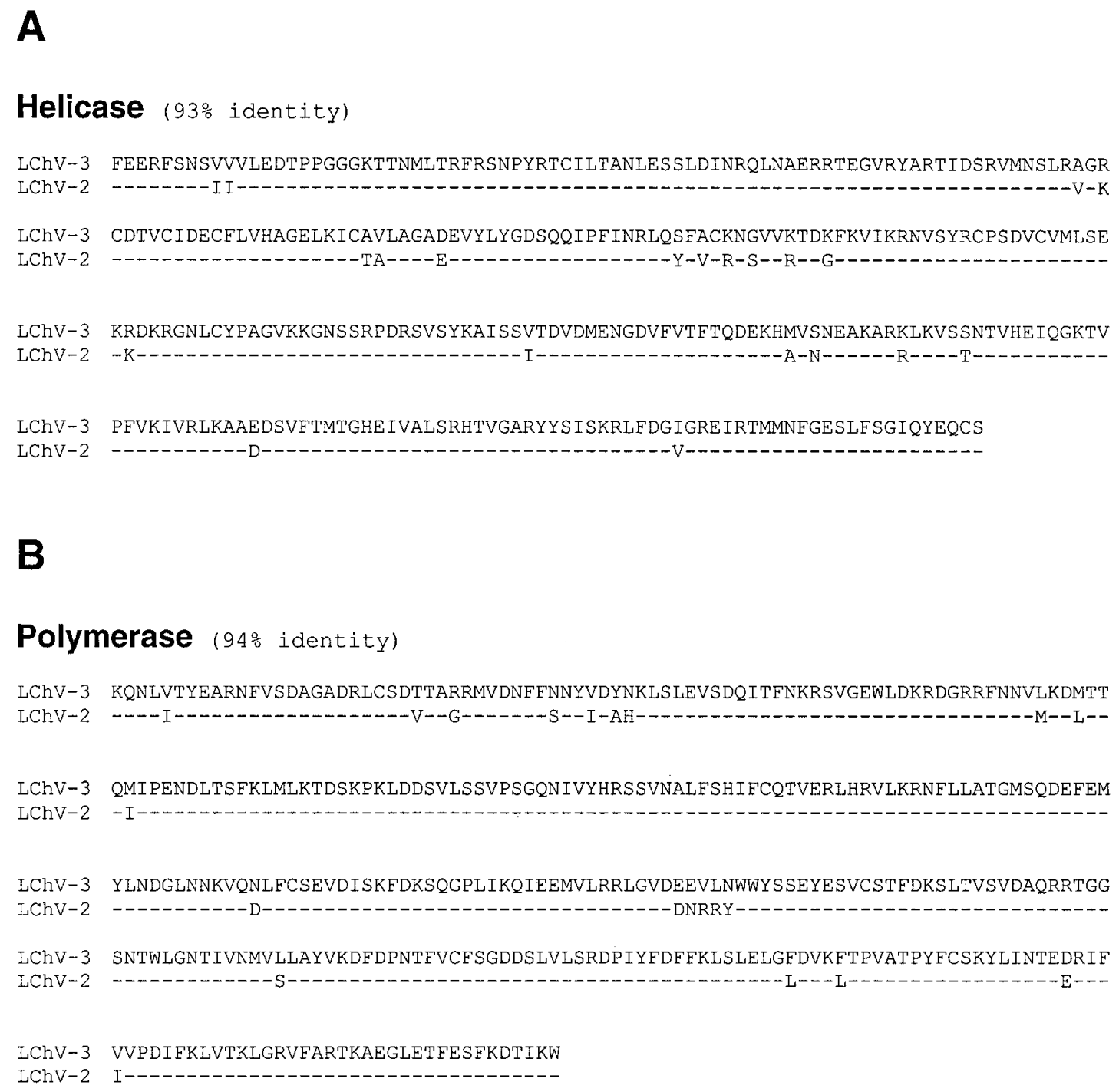

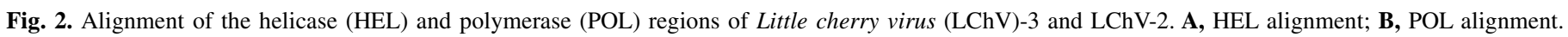
Dashes indicate identical amino acids. The percentage of identical amino acid residues in each alignment is shown in brackets. 
searches did not reveal proteins with significant sequence similarity but examination of other, similarly positioned closterovirus proteins (such as the p46 of PMWaV-2 and the p55 proteins of Grapevine leafroll-associated virus [GLRaV-1 and GLRaV-3]) indicated limited amino acid sequence identity (data not shown).

ORF7. A protein with a calculated molecular weight of 21,575 (p22) is predicted to initiate at an AUG codon at nucleotide 10,207 that is nine nucleotides downstream of ORF6. Database searches did not reveal similarity to proteins in the databases, including those of other closteroviruses. The protein contains a high proportion $(33 \%)$ of acidic residues and is also lysine rich $(17 \%)$. The significance of these unusual features is not known.

ORF8. A 141-nt intercistronic region separates ORF7 from the beginning of ORF8 at nucleotide 10,912. ORF8 has the potential to encode a protein with a predicted molecular weight of 39,034 (p39). A search of the databases revealed significant similarity to the CPs of the mealybug-transmitted closteroviruses, GLRaV-3 (28), and PMWaV-2 (31). A phylogenetic tree was constructed using the CPs and CPds of several closteroviruses. The tree in- dicated that LChV-3 p39 and p55 proteins both clustered in the same branch as the CPs of GLRaV-3 and PMWaV-2 and those of several other closteroviruses known or believed to be mealybug transmitted (data not shown). These include LChV-2 (36), PMWaV-2 (31,35), GLRaV-3 (9,28,33,38,40), GLRaV-1 $(10,18)$, GLRaV-4 (18), and GLRaV-5 (14,18). An alignment of the complete $\mathrm{CP}$ sequences of closteroviruses clustering with the LChV-3 p39 and p55 proteins was conducted. Overall, the greatest degree of amino acid sequence similarity occurred in the region of approximately 200 amino acids at the C-terminus. These aligned regions are shown in Figure 3. The alignment shows that both LChV-3 CPs contain the conserved amino acids (N, R, G, and D) present in all known closterovirus CPs (22). The possession of these amino acids reinforces the conclusion that the p39 and p55 proteins represent $\mathrm{LChV}-3 \mathrm{CPs}$. These four amino acids and two additional ones ( $\mathrm{Q}$ and $\mathrm{T}$ ) are the only amino acids conserved among all of these aligned CPs.

ORF9. The $3^{\prime}$ terminal $398 \mathrm{nt}$ of the cloned portion of the LChV-3 genome contains a partial ORF that is predicted to encode a

\begin{tabular}{|c|c|}
\hline $\mathrm{LChV}-3$ & p39 \\
\hline LChV-3 & p55 \\
\hline GLRaV-1 & $\mathrm{CP}$ \\
\hline GLRaV-I & CPAl \\
\hline GLRaV-1 & CPd2 \\
\hline PMWaV-2 & $\mathrm{CP}$ \\
\hline PMWaV-2 & $\mathrm{CPd}$ \\
\hline GLRaV-3 & $\mathrm{CP}$ \\
\hline GLRaV-3 & $\mathrm{CPd}$ \\
\hline
\end{tabular}

LChV-3 p39 LChV-3 p55 GLRaV-1 CP GLRaV-1 CPd1 GLRaV-1 CPd2 PMWaV-2 CP PMWaV-2 CPd GLRaV-3 CP GLRaV-3 CPd Consensus

\begin{abstract}
PGVM-- - YDLLEGVDDLPTVSTIGVPG--LLTAPDLLRVANNLVNFFKEKHGESDKLIINKCMVCFLQMAILHTTGD 350 PGLV-_-_.....-.--TPAVATAISTELKNLCAEVMGNTDQKSLTDFFLAMLQLMLTFSTSP 194 GRSKLNVSELDVIELTGYYNPSVMNVDDVRNVNTKLLEYFSRLYGKSESSNRAL-AIGMIQGALTWSTSA 369 GLTMVDFKGIDNITLSVSGECAYLDKDVAKKITLALLKLPLIVDNKSVYIDKRLRLILIIQGAVTYGTRA 337 PGLI-----_---_---SREIAIRIGEALKEHCKQVMGSDSSTDLATYFIHLIQLAITFSTSK 171 KAILEFLPNATQFNEADIYDERYLDEQLSLKVNTALSALCVELMGDKSRGALETLIIAMIQLCVTYSTVK 358

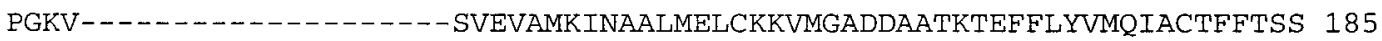
QGKICFPDSVLSINEADIYDERYLPITEALQINARLRRLVLSKGGSQTPRDMGNMIVAMIQLFVLYSTVK 348

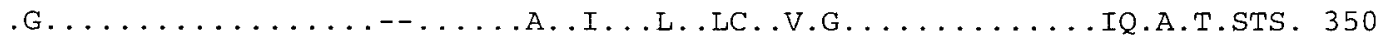

\begin{abstract}
NTKADDVEPAVIVIDGKEGVF-SYGRVRESITNPFSGTPIPNAMRRFMRAISPSIVHWLTSGLIKPNLKL 290 AATVREVTSLT-YSDGFIPKF-NYAEVCTVIKKSLDNTLYPNPVRTFLRHCSDLCIDLMIRGYIKPNIKL 418 DTESKEEYFVNLYCNGERKLT--YEKVKGAVVKGAEGSTFENPMRQYARLFSATAVHLILNGKLKPNEKV 262 NLKDGEKRKVD-VSLNGKNYTVDFNELRQIIRSSVPPSKYENPIRQYMRWFSTTTISLIKSGVVVPNYHV 438 DFVDKGSTEVI-VSYKGKSVGLDF ISVRHVIIAICGGINVTNPVRQYMRWWSTVTIQLIKLGIVKPNPIV 406 NSEYKEFDYIE--TETQRKIY--IKDVSEVVERAAMNSGYENPFRQYMRYFTSSSITLTLNGKITPNERT 237 NMI IKKEYYVE-TTYTRKLIYVSYLAIRSCIDKAVGSSFEGNALRQYMRYFTYTTVYAMRAGLVTPNYSA 427 STEFKEFDYIE--TDDGKKIY--AVWVYDCIKQAAASTGYENPVRQYLAYFTPTFITATLNGKLVMNEKV 251 NISVKDGYRVE-TELGQKRVYLSYSEVREAILGGKYGASPTNTVRSFMRYFAHTTITLLIEKKIQPACTA 417 N...KE...V.-....K....Y..VR..I........NP.RQYMR.FS.T.I.L...G..PN.. 400
\end{abstract}

LChV-3 p39 LChV-3 p5 5 GLRaV-1 CP GLRaV-1 CPd1 GLRaV-1 CPd2 PNWaV-2 CP PMWaV-2 CPd GLRaV-3 CP GLRaV-3 CPd Consensus

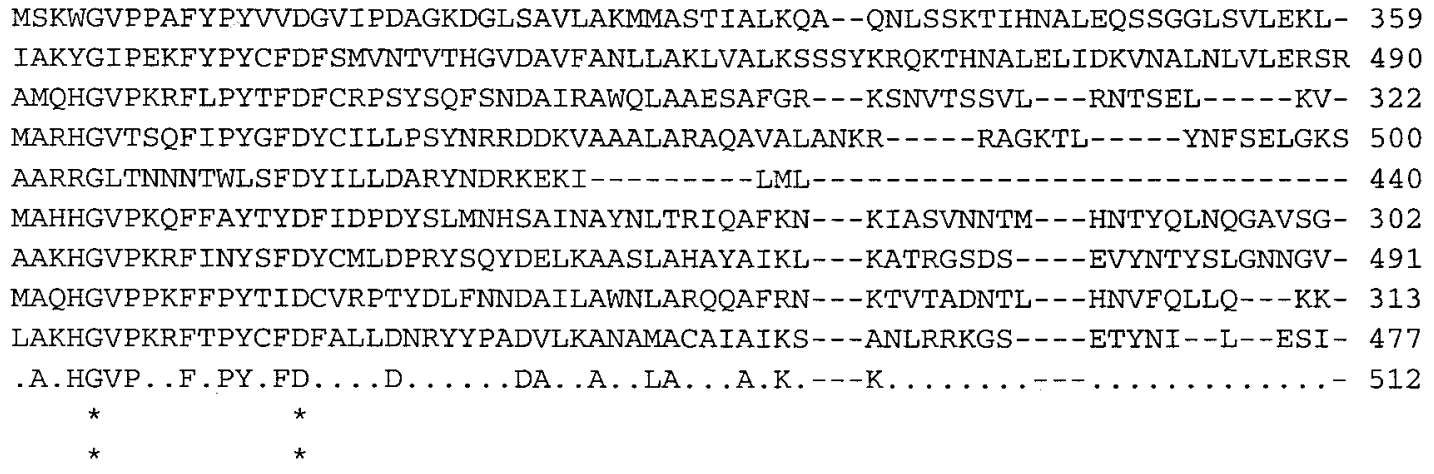

MSKWGVPPAFYPYVVDGVIPDAGKDGLSAVLAKMMASTIALKQA--QNLSSKTIHNALEQSSGGLSVLEKL- 359 IAKYGIPEKFYPYCFDFSMVNTVTHGVDAVFANLLAKLVALKSSSYKRQKTHNALELIDKVNALNLVLERSR 490 AMQHGVPKRFLPYTFDFCRPSYSQFSNDAIRAWQLAAESAFGR---KSNVTSSVL---RNTSEL-----KV- 322 MARHGVTSQFIPYGFDYCILLPSYNRRDDKVAAALARAQAVALANKR-----RAGKTL-----YNFSELGKS 500 AARRGLTNNNTWLSFDYILLDARYNDRKEKI-_-_-_-LML_MAHHGVPKQFFAYTYDFIDPDYSLMNHSAINAYNLTRIQAFKN---KIASVNNTM---HNTYQLNQGAVSG- 302 AAKHGVPKRF INYSFDYCMLDPRYSQYDELKAASLAHAYAIKI---KATRGSDS----EVYNTYSLGNNGV- 491 MAQHGVPPKFFPYTIDCVRPTYDLFNNDAILAWNLARQQAFRN---KTVTADNTL---HNVFQLLQ---KK- 313 LAKHGVPKRFTPYCFDFALLDNRYY PADVLKANAMACAIAIKS---ANLRRKGS----ETYNI--L--ESI- 477

*

Fig. 3. Amino acid sequence alignment of the C-terminal regions of the Little cherry virus (LChV)-3 p39 and p55 proteins and several closterovirus coat proteins (CPs). Bold letters correspond to amino acids conserved in all sequences and asterisks to the residues conserved in all known closterovirus CPs. A consensus sequence generated from the alignment is shown. Numbers correspond to the length of the complete protein. Abbreviations: GLRaV-1 = Grapevine leafroll associated virus 1 (10); PMWaV-2 = Pineapple mealybug wilt associated virus 2 (31); GLRaV-3 (27,28); CP = coat protein; CPd = CP duplicate.

Vol. 92, No. 1, 2002 
LChV-3 GLRaV-1 GLRaV-3 GLRaV-5 PMWaV-2 CTV LChV-1

---MNIGLDFGTTFSTAALFAS-DNKVETLKLFGDDLQPTYVYVD-RSKNFF IGNAASAKYETNLKTKSDDGWLYKDIKRWVGVNKYN - - -MEVGLDFGTTESTSCF SI PTODDSGCVSLVNS PFVPTQIF IG-SDMTYSIGHRAYSDFVAGK--- --PGGLYINPKRWVGVDSFN ---MEVGIDFGTTFSTICF SP--SGVSGCTPVAGSVYVETOIFIPEGSSTYLIGKAAGKAYRDGV---- -EGRLYVNPKRWAGVTRDN -----GLEFGTTF STLCF SAG-RGVDGCVPESDTVYIPTVVGIR-KDGTYTIG----LGALLEK-----DVLVYRDIKRYFGMINFN ---MEVGYDFGTTYSTLCYSA--EGASGCVSLFGSPYIETQVF IRADGTGYSIVNKPKALYNAKV----- PGRLYVNPKRWVGVNAYE --MVLLGLDFGTTFSTVAMATP--SELVILKQSNSSYIPTCLLLHAEPNSVSYGYDAEYLAASGES-- -- GSFYKDLKRWVGC'TAKN -MSVKVGIDFGTTFSTISGFVN --.GSFVSLLVDKTPFVPSVLAI FDGNNVVLGEQAKVISRF SDK------FVQYYDLKRWVGVSEKN $\star * \star * * * *$

LChV-3 GLRaV-1

GLRaV-3 GLRaV-5 PMWaV-2 CTV LChV-1

FNEYKTKLSSR----EYNARLEDEFTVALSWFRFIRRS ICDSSSLIALFVRGISVA IENQYGENVVSLVCTVPADYNSYKRSFLLESSK FHAVKRRLNP-- - -EYEVKIN-NGEISIGSVGNTNAPLMRVVDLVFLFVKGILLETEEAVGKAVTGVVCTVPAEYNSFKRSFLGVALE VERYVEKLKP-----TYTVKIDSGGALLIGGLGSGPDTLLRVVDVICLFLRALILECERYTSTTVTAAVVTVPADYNSFKRSFVVEALK AEVYKKKLKP-----KFEVIVK-NWSAYIGPSSGEKGKTRSVIALACMFVSALAKMAVSITGSAVKLSVCSVPAEYSSYMRNF IFQGCN LDSYVLKLKP-----VHRVEVFKDGSVMLGGIGEGPDRTVSVTDI ISLFSKALIKEAEQSTGLRVTGAVVTVPADYNSFKRSF ITNCMK YQTYLHKLSPSYKVIVKEFGTKSVPVPYLSPLNNDLGLSVALPSLIASYAKSILSDAERVFNVSCTGVICSVPAGYNTLQRAFTQQSIS FNSLKEKISP-- - - KYDCIFKNNDCYISGVGT-QKRELPIRSLIYWYLKILINLFEDQLKLKVNEVNISVPADYTTRQRIYMRS IVN $* * *$

C

LChV-3 GLRaV-1

GLRaV-3 PMWaV-2 CTV LChV -1

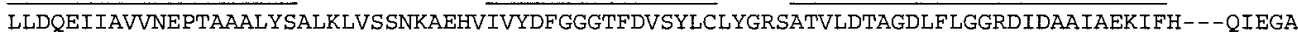
GLGKPLRALINEPTSAALYGAVKG - -GSLRETYAVF DFGGGTLDISFISRFNNVVSVLF SKGDNFLGGRDIDRAIVNFLRKEKR IKGNI GLGI PVRGVVNEPTAAALYSLAKS- -RVEDLLLAVFDFGGGTFDVSFVKKKGNILCVIF SVGDNFLGGRDIDRAIVEVIK--QKIKGKA GLGI PVRAIVNEPTPAALYSLSIL--QEKDLFLSAFDFGGGTFDVSFVRKLGDVVCVLLSVGDNFLGARDIDRAVAAEVK--ARVGESI MSGYSCVYIINEPSAAAYSTLPKLN--SADKYLAVYDFGGGTFDVSIVSVRLPTFAVRSSSGDMNLGGRDIDKKLSDKIYE-..--MADF LLGI PVRR I INEPSAAAMHQLF INP---KENNFVVFDFGGGTFDVSYIKKHGKIVSI IDTAGDLF LGGRDIDKALAEF ISQ- - - -KTGH
\end{abstract}

LChV -3 GLRaV-1 GLRaV-3 GLRaV-5 PMWaV-2 CTV LChV-1
TAKDI LSQCSNVKLDCSSEKRFVDHS IWFRDDVHKVKF SYEDF LTVMENFKNRSTKLLTQLLERNGLVDIGVNV-VMVGGSSAIPLLR DAGI LSVMIADLKEKICTNGGTQQTQVKTSNGLETLSMSVDELNAVSEPFIDRAVKIFAEGAED--LKRCPIVC-VLTGGSVALPLVR SDAKLGIFVSSMKEDLSNNNAITQHL I PVEGGVEVVDLTSDELDAIVAPFSARAVEVEKTGLDN--EYPDPVIA-VMTGGSSALVKVR SSLDPF SMESLKIDMVDNPLSTTRRVLTKTGEVKTLRFDNOOFRGLCEPFVERARAI IEKLLKR--NGVTSCVA-VLIGGSSVLPGVR DTATLSLFAASIKEEVTNEPRAKTHVVKLVDGVKLITFTSEDLNDIVRPFAARALHIYEQAAQR--YHPETSVA-VLTGGSSALQCVQ VPQKELNVSSLKEALSLQTDPVKYTVN-HYGMSETVS IDQTVLREIASVF INRTIDILTQVKVKSSMPESQSLKLVVVGGSSYLPGLL S--CDDLF INHLKETVTPGVSKNYKFVDNSGILRSVDINLSDINSVAQPF INKSLKLLDSVISRNH ISKA - - - LVCMVGGTSMLDGTY

\section{$\mathbf{F}$}

\section{G}

LChV-3 GLRaV-1 GLRaV-3 GLRaV-5 PMWaV-2 CTV LChV -1

DAVAAYRGVKRVVFDNNTFRIAVAVGAKVYSDSLVSNKGLVLVDTLSHAILDEIVGLKAKVVVGKGQVVPST----AEINYGF SGGNM PKLENLPYVSSVAYDSQTFRLSVAIGAKIYGDILTGQSDLRLIDTVSQTLSDELSGFTELVIFPKGHPVPSV----YETSFQVSGSTM SDVANLPQISKVVFDSTDFRCSVACGAKVYCDTLAGNSGLRLVDTLTNTLTDEVVGLQPVVIF PKGSPIPCS----YTHRYTVGGGDV NSVAGLKEISRVI FDKETYRVAVAIGAAIYAQTFTGVSRYRLIDCVSNSLSDERQPLQAITVF PKGHPIPST----VAVNFKMPTYNT FALTASKYDSKVVFDKGDFRASDSYSAKIYCDI LAGASKLRLVDTLTNTLSDEVLNFRPVIVF SKGSVI PSE----RTITFNTGGRKT DALATVPFVSGIVPVE-DARTAVATGCALYSECLDGRSKALLIDCITHHLSVTTFSADSVVVAAAGSPI PFEGEQKLTLRKCVSTSNY NSVTKYCDSKGLKVFRSEHLRSSVAYGCA ILHDFDSDKDF IYVDVNSHGLIDVGHHFVPRVIMRKPLSIPYS - - ISFDLTNKLKYST

H

LChV -3 GLRaV-1 GLRaV-3 GLRaV-5 PMWaV-2 CTV LChV-1

LChV-3

GLRaV-1 GLRaV-3

GLRaV -5 PMWaV-2

CTV $\mathrm{LChV}-1$

RIDVYEGEHPMAFMN_-_...-EPTYTSSVLTEKAG-_-TVPVRYELRRDGSLIVSVFGKQIKNKFLPKG-RLKPNEYNYSDPDVEYRN EYGIFEGESNRTWMN-----EIAFKG-TDYRPSNERKNDKVKYEISVDGKLKLSVDGRELKNTRLPAPVSLSAHSYRYVSSMKKYLV VYGIFEGENNRAF LN- - - - EPTFRG-VSKRRGDPVETDVAQFNLSTDGTVSVIVNGEEVKNEYLVPGTTNVLDSLVYKSGREDLEA GVVLHEGESSF INEN - ......ARTYSAPLRTSQF PGGRTYVNEFKILEDGRLDVTMNGVPLINEVVPERPLDEEYSEVFLSSDDKRIK MYGVYEGEEVRSYLN-----ALTFRG-EYISNVEGNRTDSATF SVSSDGILSVSVNGTLLKNDLVPSPPTVF SKNLEYLSNIEKVAN QARMFEGDYEKVFRNERIYAAS I SLFTLGVNWSVPNDVEMTLVTKVD SMGKVEFYLKGPSGELVNVQGTSHYDYAGMPHPTRKLVRLS AACVYEGDSLNFLEND-----LLVNATFFTDEVSDLGSGYRLTYSYDIEGKLSVSISSIDGTKFKNLENKVDSNFELVKLDLIQTQLS

DGLMSYATDVCRVLGSAVTLSDTDPYNVCKKIDDLVDKNTS-_OLENNYVDMF SELHGDKISIDDVYNDTGAYFDKSILVNFSRLS KAI PEYLTTLNI LHDKAFTRRNLGNKDKGF SDLRIEENF LKSAVDTDTILNGPEVNDIKLFYSKILNQPSLSTKDLAARREEYIKNGIVCDEGI PEYARQFMALYGQRISREEI LADVGAFKEHK IVENYSKRWLDYNVNSAALVLALTLTREKREKFLLRTLFDTLLADLRKTASLGEYSKKYPITRNDIDVVSSRMGIVVSKVLRGSDLERIPL--- - SSA IYSVIVSLSKYWGINPELKHLAIEFPYL IKDF IDKNGGLEEYVDRIRNEIGAFVDSLDERLVVRLLF ILDGVFKFYYLSNCKHI

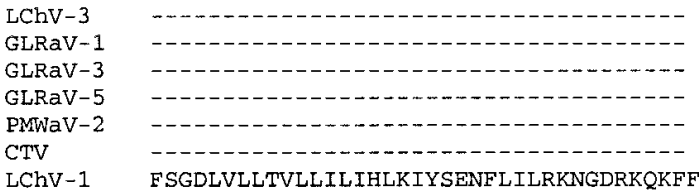

Fig. 4. Alignment of the HSP70 homologue of Little cherry virus (LChV)-3 with those of other closteroviruses. Conserved motifs present in cellular HSP70 proteins $(\mathrm{A}-\mathrm{H})$ are overlined. Asterisks correspond to residues shared by all of the viruses shown. Double asterisks indicate the subset of residues shared by all closteroviruses. Abbreviations: GLRaV-5= Grapevine leafroll associated virus 5 (14); PMWaV-2 = Pineapple mealybug wilt associated virus 2 (31); CTV = Citrus tristeza virus (19). 
protein with a minimum molecular weight of 15,017 . ORF9 does not contain a terminator codon; therefore, the actual length of the ORF or the molecular weight of the putative protein product is not known.

Phylogenetic comparisons. A phylogenetic analysis of amino acid sequences comprising the LChV-3 HEL region, POL region, and the HSP70 homologue with those of other closteroviruses was conducted. Dendograms depicting phylogenetic relationships between these sequences are shown in Figure 5. In each of the dendograms, it can be seen that LChV-3 exists in a separate branch along with other closteroviruses known or believed to be mealybug transmitted. Based on these dendograms, LChV-3 is most closely related to $\mathrm{LChV}-2$, which has also been suggested to be mealybug transmitted (36). Only a distant relationship exists between LChV-3 and LChV-1, which has been shown previously to branch with whitefly-transmitted closteroviruses $(18,22)$.

Expression and purification of LChV-3 CPs in E. coli and production of polyclonal antisera. The $\mathrm{p} 39 \mathrm{CP}$ ORF was cloned into the bacterial expression vector such that the CP C-terminus was fused with the His-tag present in the vector. Expressed protein was purified by affinity chromatography. A similar approach failed to yield sufficient quantities of p55 protein; therefore, the p55 ORF was fused to the maltose-binding protein ORF and purified by affinity chromatography. Polyclonal antisera produced against each purified bacterially expressed protein were tested for their ability to detect the fusion protein as well as LChV-3 in infected leaf extracts and in purified virions using western blot analysis. Antiserum to the $\mathrm{p} 39$ protein reacts to the bacterially expressed p39 protein as well as to a protein with an estimated size of $39 \mathrm{kDa}$ in LChV-3-infected leaf extracts and purified virions (Fig. 6). The antiserum did not react to extracts from uninfected leaves. Antiserum to the p55 protein reacted to bacterially expressed p55 protein (Fig. 6B) and to a 55-kDa protein and a $21-\mathrm{kDa}$ protein in purified virions, but did not react to proteins in infected or uninfected leaf extracts. The ability of the p39 antiserum to specifically detect a $39-\mathrm{kDa}$ protein in infected leaves and purified $\mathrm{LChV}-3$ virion preparations reinforces the conclusion that the $\mathrm{p} 39$ protein represents a LChV-3 CP. In addition, the fact that the antiserum does not react to other proteins present in infected leaf extracts or to proteins present in uninfected extracts suggested that this antiserum may be useful for ELISA-based detection. The ability of the $\mathrm{p} 55$ antiserum to detect a $55-\mathrm{kDa}$ protein in virion preparation reinforces the conclusion that the $\mathrm{p} 55$ protein is also a LChV-3 CP. Lack of detection of a protein in infected leaf extracts may suggest that the p55 protein does not accumulate to sufficiently high levels in leaves to permit detection. The origin of the $21-\mathrm{kDa}$ protein in virion preparations (Fig. 6 ) is not known, but it may be a specific breakdown component of the 55-kDa protein.

Development of an ELISA-based diagnostic test for LChV-3. A modified DAS-ELISA procedure was developed to detect LChV-3 in infected cherry leaves. This procedure involved using p39 IgG to trap $\mathrm{LChV}-3$ virions extracted from infected cherry leaves, followed by incubation with biotin-labeled p39 $\mathrm{IgG}$ and detection of biotin-labeled antibody using streptavidin conjugated to alkaline phosphatase. LChV-3 p39 IgG (at $0.5 \mu \mathrm{g}$ per well) was found to be effective in capturing LChV-3 and detection was possible in cherry leaves when sap was diluted up to 1:1,280. At this dilution the absorbance value (optical density at $405 \mathrm{~nm}$ ) for infected leaf sap was, on average, 0.090 and that of healthy leaf sap was 0.011 (data not shown). Little or no detectable reaction occurred to healthy leaf sap at any concentration (data not shown). Attempts to detect LChV-3 in infected cherry leaves using the LChV-3 p55 IgG were not successful.

LChV-3 infection in British Columbia, Canada. LChD has resulted in serious economic losses in cherries in the Interior region of British Columbia, Canada. LChD was first detected in 1933 in the Kootenay Valley. The disease spread rapidly and eventually affected all orchards and all trees within the orchards. By 1979, production had dropped 90\% (42). Control measures for LChD have since been implemented. These include removal of infected trees, use of certified stock, and control of the apple mealybug vector. Removal measures and certification require precise and preferably rapid and inexpensive identification of LChD. Previous methods have relied on woody indexing but, more recently, an RT-PCR test has been developed (6). We wanted to evaluate the possibility of using an ELISA-based test for identification of LChV-3. To investigate this, p39 antiserum was used to

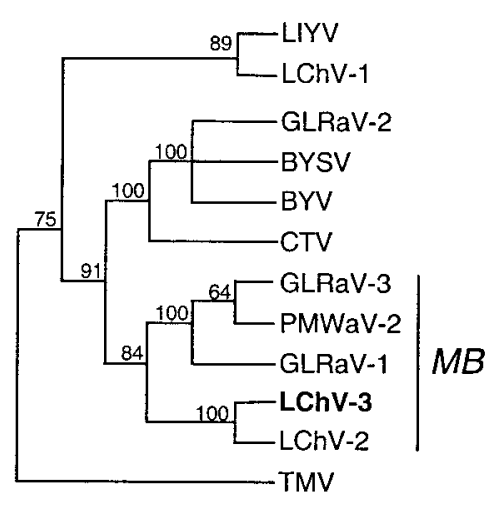

$H E L$

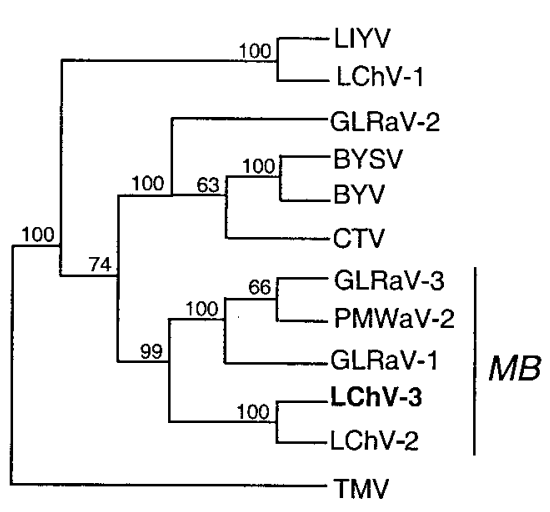

POL

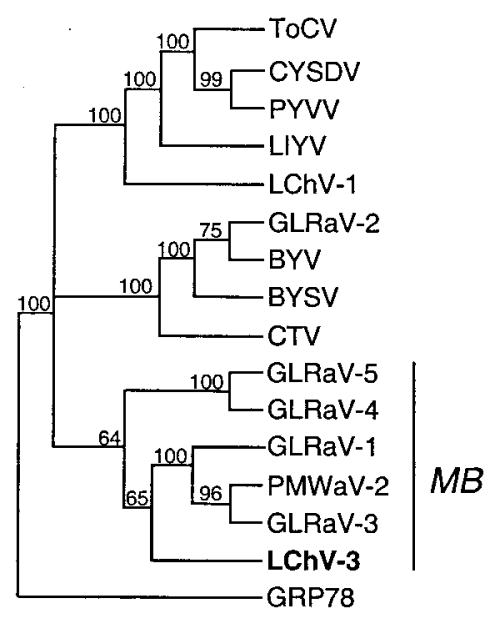

HSP70

A

C

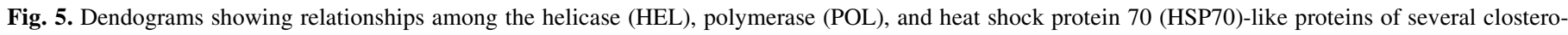

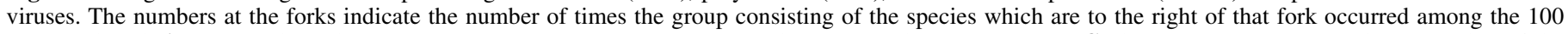

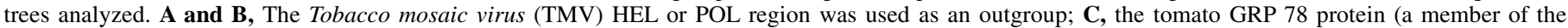

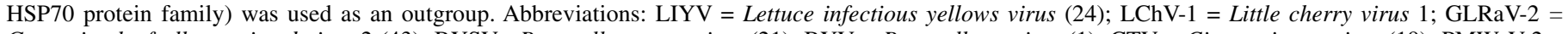

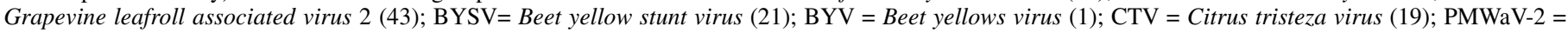
Pineapple mealybug wilt associated virus 2 (31); $\mathrm{MB}=$ mealybug-transmitted viruses. 
conduct a preliminary survey for LChV-3 infection of cherry trees in southern British Columbia. In all, 935 samples were collected from 138 commercial and residential orchards in several cherrygrowing districts in the Okanagan and Kootenay Valleys (Fig. 7). Samples were collected between 26 June and 23 August 2000 from 94 Okanagan properties and 44 properties in the Creston area (in the Kootenay Valley). Orchards in areas with a history of $\mathrm{LChD}$ as well as orchards with no known history were examined. Trees with LChD symptoms were targeted for sampling. Where no symptoms were present, random samples were collected. Ten leaf samples collected from the base of new shoots from symptomatic branches of an individual tree were combined and used for the ELISA test. All positives were located in either Penticton, which lies in the Okanagan Valley, or Creston, which is approximately $300 \mathrm{~km}$ southeast of Penticton in the Kootenay area of British Columbia (Fig. 7). Of the 531 samples collected in Penticton, $85(16 \%)$ were positive. Of the 139 samples collected in Creston, 17 (12.2\%) were positive. All of the LChV-3-positive samples showed typical LChV-3 symptoms. An RT-PCR test utilizing primers to a portion of the LChV-3 RdRp coding sequence (6) was used to validate the results of the ELISA-based LChV-3 survey. Of the surveyed 935 samples, 122 were tested, in which 20 were positive and 102 were negative by ELISA. The RTPCR analysis gave identical results. These results indicate that p39 antiserum may be useful for a more large-scale survey for LChV-3 incidence.

\section{DISCUSSION}

The genome of LChV-3 was previously estimated to be approximately $12.6 \mathrm{~kb}$ in length based on electrophoresis of dsRNA extracted from infected cherry leaves $(5,7)$. The sequence we report here is $12,447 \mathrm{nt}$, which is close to the estimated size. However, our sequence of LChV-3 lacks the methyltransferase motif and a motif for one or two papain-like proteases (4) that are present in most closteroviruses sequenced to date (Fig. 8). In addition, most closteroviruses contain one to several ORFs downstream of the CP ORF (Fig. 8) (18,31). Our sequence terminates just downstream of the CP ORF and includes a partial ORF for a protein larger than $15 \mathrm{kDa}$. Several attempts to obtain sequences beyond the cloned regions described here were unsuccessful. It is possible that the previous method used to estimate the LChV-3 genome length did not adequately predict the actual size. Alternatively, LChV-3 may lack the methyltransferase and protease, or the coding sequences for these proteins may lie on another unidentified genome segment. Further experiments are required to distinguish between these possibilities.

The nucleotide sequence of a $\approx 5,900$-nt region of the LChV-2 genome was previously reported (36). The sequenced region includes the HEL and POL coding region and the sequence upstream from these regions. A comparison of the amino acid sequences of the HEL and POL motifs of LChV-3 and those of the recently reported LChV-2 sequences shows 93 and $94 \%$ identity, respectively (Fig. 2). Similar comparisons at the nucleotide sequence level reveal $77 \%$ overall identity $(3,611$ identities in the 4,696 nt compared) but with higher conservation of nucleotide sequence in the HEL and POL coding regions (data not shown). A very low level of sequence identity $(\approx 66 \%)$ occurred in the region upstream of the HEL motifs. The low overall nucleotide sequence identity in the compared regions (which are generally the most conserved genomic regions) suggests that LChV-3 should be considered a distinct virus.

Sequence analysis of several isolates inducing $\mathrm{LChD}$ in the Okanagan and Kootenay Valleys of British Columbia indicates $\approx 1$ to $20 \%$ divergence in portions of their genomes (D. Rochon and J. Theilmann, unpublished data). A large number of divergent isolates inducing LChD have been reported $(5,6)$. Thus, LChV-3 is likely to be a highly variable virus. This should be taken into consideration in programs to detect and control LChD.

The complete sequence of a closterovirus (LChV-1) associated with LChD in Germany has previously been reported (16). This virus was presumed to be mealybug transmitted, based on the fact that it caused symptoms similar to mealybug-transmitted LChD in British Columbia and also because a closterovirus was the suggested etiological agent of LChD in Canada. Sequence comparisons between LChV-3 and LChV-1 show that these viruses are
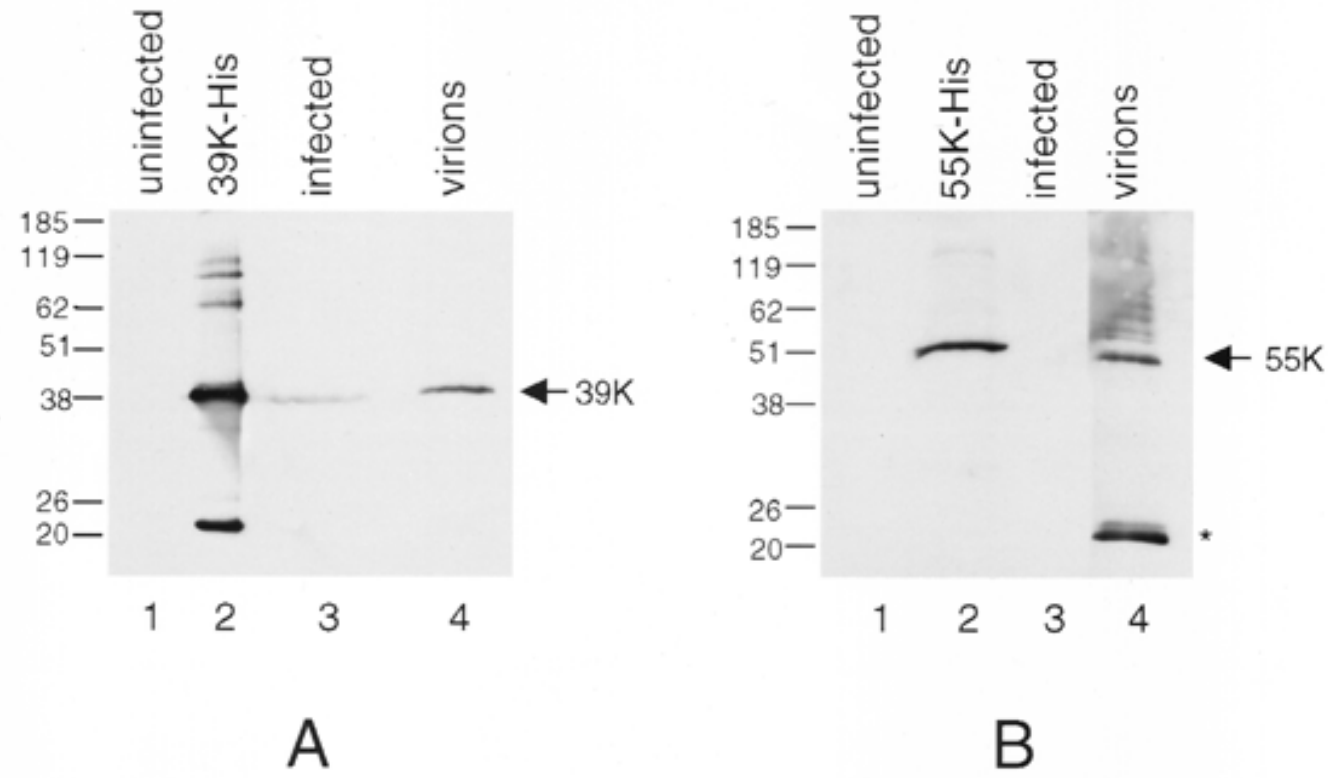

Fig. 6. Western blot analysis of total proteins extracted from Little cherry virus (LChV)-3-infected or uninfected cherry leaves. Proteins were separated by electrophoresis through $12 \%$ polyacrylamide gels containing sodium dodecyl sulfate and incubated with antisera to either A, LChV-3 p39 protein or B, LChV-3 p55 protein. Lane 1 contains total protein from uninfected cherry leaves, lane 3 contains total protein from infected cherry leaves, and lane 4 contains purified LChV-3 virions. Lane 2 contains bacterially expressed A, polyhistidine (His)-tagged 39K protein or B, His-tagged p55 protein. Numbers on the left correspond to sizes in kilodaltons of protein molecular mass standards. The position of the p39 and p55 LChV-3 coat proteins in lane 2 is indicated along with the position of the 39- and 55-kDa proteins in infected leaf extracts and virions. The asterisk in $\mathbf{B}$ corresponds to a $21-\mathrm{kDa}$ protein that was sometimes detected in virion preparations. The extra bands in lane 2 of $\mathbf{A}$ correspond to bacterial proteins that copurified with the p39 protein. 
only remotely related. As previously described (16) and as shown here (Fig. 5), several LChV-1 gene products cluster with those of the whitefly-transmitted closteroviruses. In contrast, the HEL, POL, and HSP70 proteins of LChV-3 cluster in a separate branch along with other mealybug-transmitted closteroviruses and the previously reported HEL and POL sequences of LChV-2. Thus, it is likely that symptoms associated with LChD may be caused by at least three independent viruses.

Phylogenetic analyses show that the HEL, POL, HSP70, and two CPs of LChV-3 cluster in a separate branch with the corresponding proteins of several mealybug-transmitted closteroviruses. Similar results were obtained using the HEL and POL sequences of LChV-2 (36) and a portion of the POL region of the LChV-3 (6). The LChV-3 isolate used in this study was originally derived from a cherry tree that had been infected using mealybugs (5), whereas the vector for LChV-2 has not yet been determined. The clustering of several protein sequences of LChV3 with mealybug-transmitted closteroviruses supports the pro- posal by Karasev (18) that closterovirus classification could be based on vector type. Finally, the apparent whitefly-transmitted nature of LChV-1 suggests that LChD may involve more than one vector.

Although we have clearly demonstrated that LChV-3 is part of the closterovirus lineage, it nevertheless shows distinctive properties. The two CP ORFs are separated from each other in the genome and one of the CP ORFs lies upstream from the HSP70 homologue ORF rather than downstream as reported in other closteroviruses (Fig. 8). This distinctive genome organization was confirmed by resequencing RT-PCR products covering the entire genome. The primer pairs used for the RT-PCR corresponded to regions of independent cDNA clones in order to resequence the overlapping regions of clones and confirm their relative locations (Fig. 1). The distinctive organization of the LChV-3 CP genes suggests that recombination has occurred during the evolution of this virus. The significance of this observation in regards to genome expression is not yet known but it may be considered to

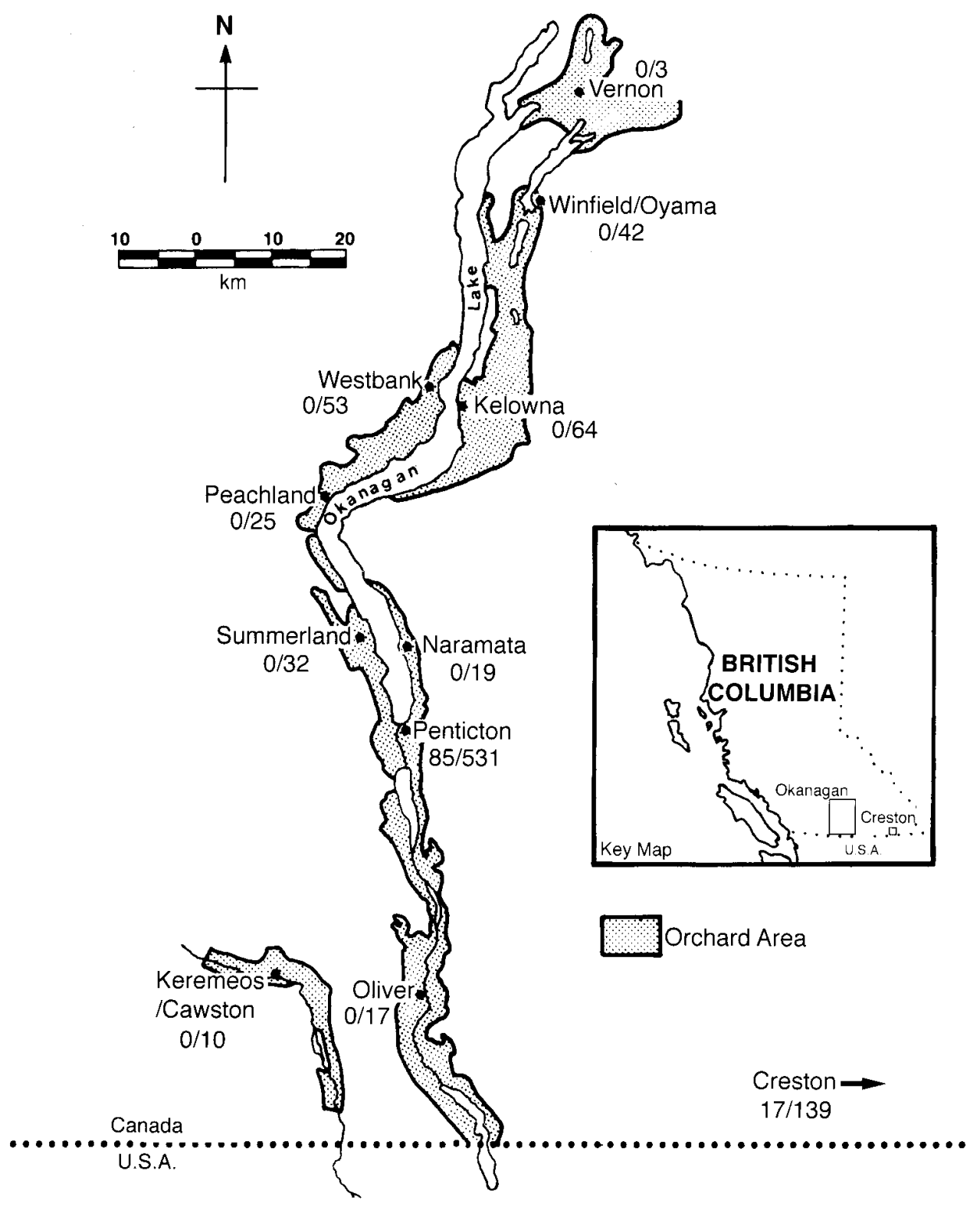

Fig. 7. Map of the Okanagan and Creston areas of Southern British Columbia showing collection sites for the Little cherry virus (LChV) survey. A map of British Columbia showing the location of the Okanagan Valley and the Creston area is shown in the inset. Cherry-growing districts are shown along with the incidence of LChV-3 infection found in a noncomprehensive survey of the area. The numbers next to the growing districts indicate the number of positive samples obtained versus the number of samples collected. The survey was conducted using LChV-3 p39 antisera. The map was modified from Kerr et al. (23). 
have relevance to the classification of LChV-3. The importance of recombination in closterovirus diversity has previously been discussed (4).

GLRaV-1, GLRaV-3, and PMWaV-2 each contain long intercistronic regions (LIRs) in similar positions in their genomes (Fig. 8 ). These regions are 793, 1,067, and 624 nt long, respectively. LChV-3 contains two LIRs (LIRa and LIRb) of $280 \mathrm{nt}$ and $232 \mathrm{nt}$ (Fig. 8). The LIRs in LChV-3 are separated by a potential coding region for a 51-amino acid protein. It is peculiar that each of the mealybug-transmitted viruses contain LIRs in this area of the genome, whereas other closteroviruses (Fig. 8) either lack this region or contain an ORF for an approximately $33 \mathrm{~K}$ protein.

Database searches were conducted to determine if the region upstream from the HEL motif in LChV-3 is similar to any other known sequences. Surprisingly, significant amino acid sequence similarity was found to proteins encoded by several long filamentous positive-strand RNA viruses, including capilloviruses, trichoviruses, vitiviruses, carlaviruses, potexviruses, allexiviruses, and foveaviruses, as well as the closterovirus GLRaV-3. Moreover, a similar conserved sequence was found in several plant and animal proteins as well as in several prokaryotic and fungal proteins (data not shown).

The inability of the p55 antiserum to react to infected leaf extracts may be due to low accumulation or instability of the p55 protein in infected leaves. Closteroviruses are known to encode at least two CPs, with one CP being derived by duplication of the other (18). The CPds have been shown to be a minor component of virions, corresponding to $\approx 5 \%$ of the length of the virion rod at one end. It is possible that the p39 protein corresponds to the $\mathrm{CP}$ and p55 to the CPd. This tentative conclusion is partly based on the apparent relative abundance of p39 and p55 in leaf tissue but also on the sizes of the p39 and p55, which approximate the p35 and p53 CP and CPd, respectively of GLRaV-3 (27,28). However, further studies are required before determining the actual relative abundance of these two CPs in LChV-3 virions and for assigning them as the $\mathrm{CP}$ or $\mathrm{CPd}$.

Eastwell and Bernardy (6) reported that purified LChV-3 virions yield mainly a $22.4-\mathrm{kDa}$ band and also contain a minor $21.6-\mathrm{kDa}$ band. Our p55 antisera also occasionally reacted to an $\approx 21$-kDa protein in stored virus preparations. It is possible that the observed $21-\mathrm{kDa}$ protein corresponds to a specific breakdown component of the $55-\mathrm{kDa}$ protein. Its possible significance in virion preparations remains to be determined.

A noncomprehensive survey for LChV-3 infection in the British Columbia Interior was conducted using p39 antisera developed. Positive reactions were obtained for $10.9 \%$ of surveyed trees. All positive samples showed typical LChD symptoms. Identical results were obtained using either the ELISA test or an RT-PCR

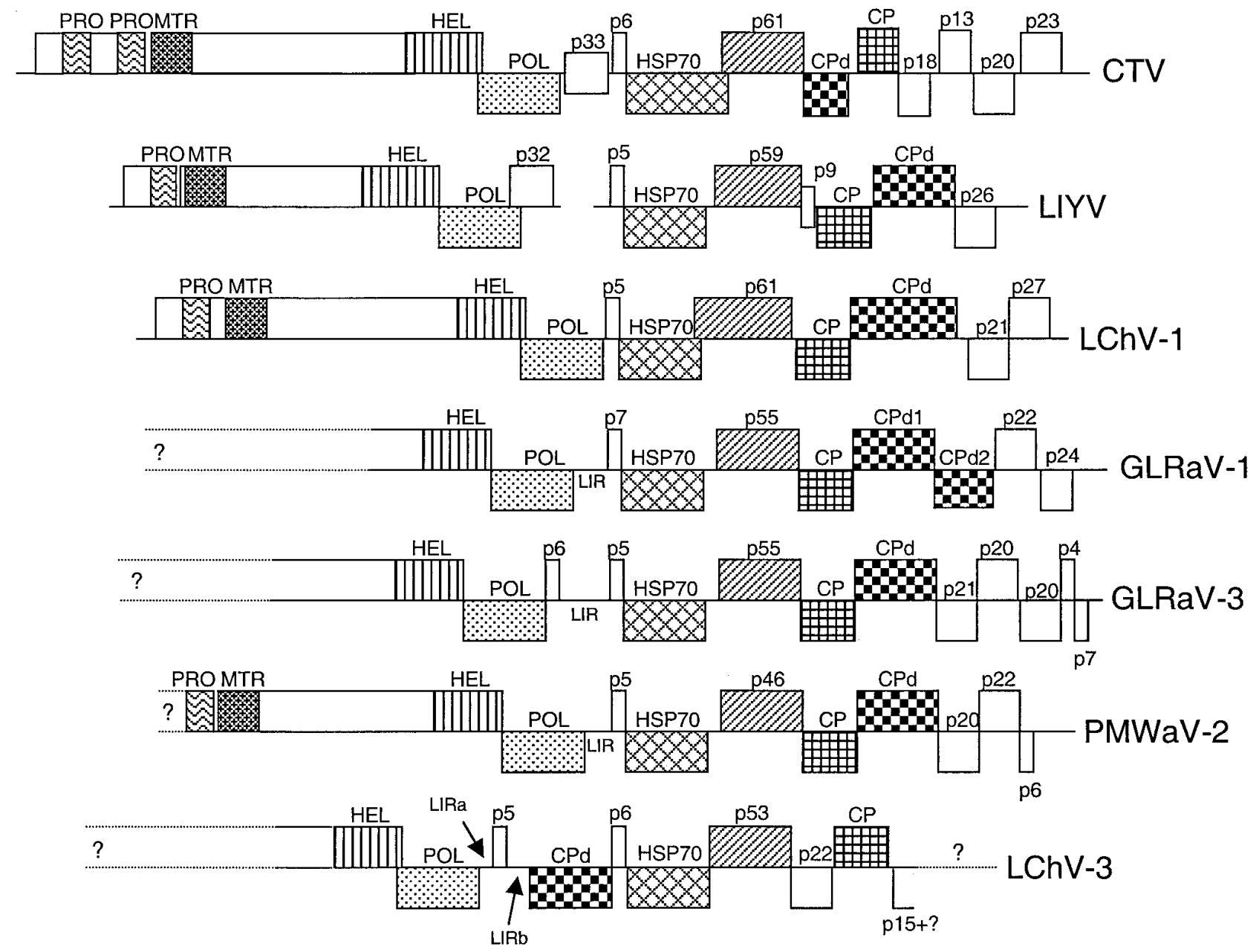

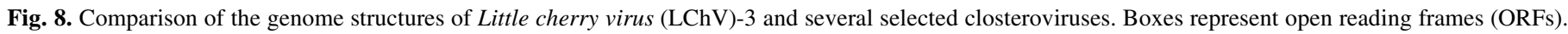

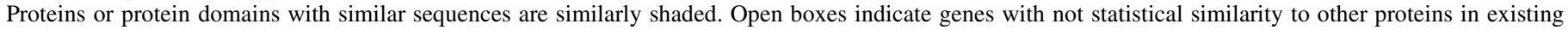

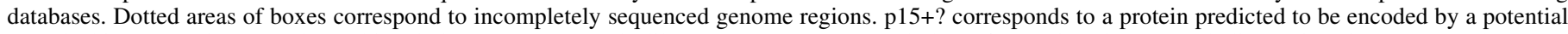

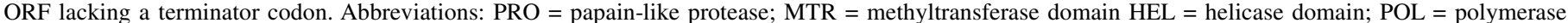

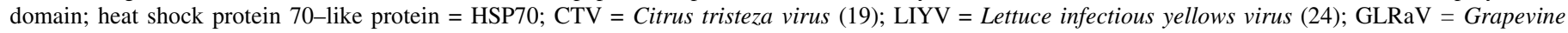

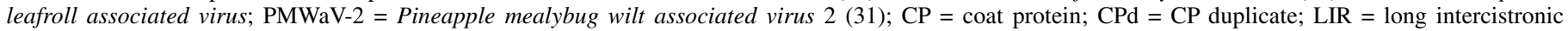
region. 
test. RT-PCR tests for the detection of LChV-3 (6) and LChV-2 (36) have been reported. A survey comparing both these methods and using our p39 antiserum for the DAS-ELISA may be useful in assessing the relative strengths and weaknesses of the methods.

LChV-3 p39 antiserum was tested for its ability to react to several LChV-3 variants collected from British Columbia (7) and from an isolate from the Netherlands and an isolate from Germany originally from flowering cherry. Several of the isolates gave positive reactions (J. Theilmann and D. Rochon, unpublished data), suggesting that the p39 antiserum may be useful in detecting a wide range of isolates. In addition, partial sequence analysis of several isolates reacting to our anti-p39 antiserum showed sequence identity ranging from $\approx 80$ to $100 \%$. A largescale survey for LChV-3 infection was carried out in British Columbia in summer 2001 with this antiserum to help assess its usefulness in $\mathrm{LChD}$ detection.

An approach similar to the one described here involving expression of viral CP in bacterial cells has been successfully used to prepare diagnostic antisera to other closterovirus CPs $(15,20$, $28,29,32$ ). Thus, bacterial expression of $\mathrm{CP}$ antigens may be a generally successful method for closterovirus detection.

Detection of LChV-3 has previously relied on woody indexing, which is time consuming and unreliable. Identification of infected trees requires accurate diagnostic tests to distinguish LChV-3 infection from other factors, such as nutritional deficiencies. The modified DAS-ELISA test developed in this study is a rapid, sensitive, and reliable means for detecting LChV-3 in infected trees. This method will provide a means for effective control of this potentially devastating virus.

\section{ACKNOWLEDGMENTS}

AAFC contribution 2110. This work was partially supported by funds from the Okanagan/Kootenay Cherry Growers Association and the British Columbia Investment Agriculture Foundation. We acknowledge the use of the Canadian Bioinformatics Resource in this research. We thank P. Neilsen for excellent technical assistance on the LChV-3 survey; D. Theilmann for critically reviewing the manuscript; and D. Thompson, of the Canadian Food Inspection Agency, Centre for Plant Health, for providing other LChD samples during the course of this work.

\section{LITERATURE CITED}

1. Agranovsky, A. A. 1994. Beet yellows closterovirus: Complete genome structure and identification of a leader papain-like thiol protease. Virology 198:311-324.

2. Clark, M. F., and Adams, A. N. 1977. Characteristics of the microplate method of enzyme-linked immunosorbent assay for the detection of plant viruses. J. Gen. Virol. 34:475-483.

3. Devereux, J., Haeberli, P., and Smithies, O. 1984. A comprehensive set of sequence analysis programs for the VAX. Nucleic Acids Res. 12:387395.

4. Dolja, V. V., Karasev, A. V., and Koonin, E. V. 1994. Molecular biology and evolution of closteroviruses: Sophisticated build-up of large RNA genomes. Annu. Rev. Phytopathol. 32:261-85.

5. Eastwell, K. C., and Bernardy, M. G. 1996. Association of high molecular weight double-stranded RNA with little cherry disease. Can. J. Plant Pathol. 18:203-208.

6. Eastwell, K. C., and Bernardy, M. G. 2001. Partial characterization of a closterovirus associated with apple mealybug-transmitted little cherry disease in North America. Phytopathology 91:268-273.

7. Eastwell, K. C., Bernardy, M. G., and Li, T. S. C. 1996. Comparison between woody indexing and a rapid hybridization assay for the diagnosis of little cherry disease in cherry trees. Ann. Appl. Biol. 128:269-277.

8. Eastwell, K. C., and Li, T. S. C. 1994. Status of the little cherry disease eradication program in the Kootenay Valley of British Columbia. Can. Plant Dis. Surv. 74:115-116.

9. Engelbrecht, D. J., and Kasdorf, G. G. F. 1990. Transmission of grapevine leafroll disease and associated closteroviruses by the vine mealybug Planococcus ficus. Phytophylactica 22:341-346.

10. Fazeli, C. F., and Rezaian, M. A. 2000. Nucleotide sequence and organization of ten open reading frames in the genome of grapevine leafroll- associated virus 1 and identification of three subgenomic RNAs. J. Gen. Virol. 81:605-615.

11. Felsenstein, J. 1985. Confidence limits on phylogenies: An approach using the Bootstrap. Evolution 39:783-791.

12. Fitch, W. M., and Margoliash, E. 1967. Construction of phylogenetic trees. Science 155:270-284.

13. Foster, W. R., and Lott, T. B. 1947. "Little cherry", a virus disease. Sci. Agric. 27:1-6.

14. Good, X., and Monit, J. 2001. Partial genome organization, identification of the $\mathrm{CP}$ gene and detection of Grapevine leafrollassociated virus-5. Phytopathology 91:274-281.

15. Hoyer, U., Maiss, E., Jelkmann, W., Lesemann, D.-E., and Vetten, H. J. 1996. Identification of the coat protein gene of a sweet potato sunken vein closterovirus isolate from Kenya and evidence for a serological relationship among geographically diverse closterovirus isolates from sweet potato. Phytopathology 86:744-750.

16. Jelkmann, W., Fechter, B., and Agranovsky, A. A. 1997. Complete genome structure and phylogenetic analysis of little cherry virus, a mealybug-transmissible closterovirus. J. Gen. Virol. 78:2067-2071.

17. Jespersen, G. D., and Carter, G. 1994. Little cherry virus survey in the Okanagan Valley of British Columbia. Can. Plant Dis. Surv. 74:117.

18. Karasev, A. V. 2000. Genetic diversity and evolution of closteroviruses. Annu. Rev. Phytopathol. 38:293-324.

19. Karasev, A. V., Boyko, V. P., Gowda, S., Nikolaeva, O. V., Hilf, M. E., Koonin, E. V., Niblett, C. L., Cline, K., Gumpf, D. J., Lee, R. F., Garnsey, S. M., Lewandowski, D. J., and Dawson, W. O. 1995. Complete sequence of the citrus tristeza virus RNA genome. Virology 208:511520 .

20. Karasev, A. V., Nikolaeva, O. V., Lee, R. F., Wisler, G. C., Duffus, J. E., and Dawson, W. O. 1998. Characterization of the beet yellows stunt virus CP gene. Phytopathology 88:1040-1045.

21. Karasev, A. V., Nikolaeva, O. V., Mushegian, A. R., Lee, R. F., and Dawson, W. O. 1996. Organization of the $3^{\prime}$-terminal half of beet yellow stunt virus genome and implications for the evolution of closteroviruses. Virology 221:199-207.

22. Keim-Konrad, R., and Jelkmann, W. 1996. Genome analysis of the 3'terminal part of the little cherry disease associated dsRNA reveals a monopartite clostero-like virus. Arch. Virol. 141:1437-1451.

23. Kerr, M. A., Manning, E. W., Seguin, J., and Pelton, L. J. 1985. Okanagan fruitlands: Land-use change dynamics and the impact of federal programs. Lands Directorate, Environment Canada. Land Use in Canada Ser. No. 26.

24. Klaasen, V. A., Boeshore, M. L., Koonin, E. V., Tian, T., and Falk, B. W. 1995. Genome structure and phylogenetic analysis of lettuce infectious yellows virus, a whitefly-transmitted, bipartite closterovirus. Virology 208:99-110.

25. Koonin, E. V., and Dolja, V. V. 1993. Evolution and taxonomy of positive-strand RNA viruses: Implications of comparative analysis of amino acid sequences. Crit. Rev. Biochem. Mol. Biol. 28:375-430.

26. Laemmli, U. K. 1970. Cleavage of structural proteins during the assembly of the head of bacteriophage T4. Nature (Lond.) 227:680-685.

27. Ling, K.-S., Zhu, H. Y., Alvizo, H., Hu, J. J., Drong, R. F., Slightom, J. L., and Gonsalves, D. 1997. The CP gene of grapevine leafroll associated closteroviruses-3: Cloning, nucleotide sequencing and expression in transgenic plants. Arch. Virol. 142:1101-1116.

28. Ling, K. S., Zhu, H. Y., Drong, R. F., Slightom, J. L., McFerson, J. R., and Gonsalves, D. 1998. Nucleotide sequence of the $3^{\prime}$-terminal twothirds of the grapevine leafroll-associated virus-3 genome reveals a typical monopartite closterovirus. J. Gen. Virol. 79:1299-1307.

29. Ling, K.-S., Zhu, H.-Y., Jiang, Z.-Y., McFerson, J. R., and Gonsalves, D. 1997. Using antibodies developed against recombinant coat protein to detect grapevine leafroll associated closterovirus-3. (Abstr.) Phytopathology 87(suppl.):S58.

30. Lipman, D. J., and Pearson, W. R. 1985. Rapid and sensitive protein similarity searches. Science 227:1435-1441.

31. Melzer, M. J., Karasev, A. V., Sether, D. M., and Hu, J. S. 2001. Nucleotide sequence, genome organization and phylogenetic analysis of pineapple mealybug wilt-associated virus-2. J. Gen. Virol. 82:1-7.

32. Nikolaeva, O. V., Karasev, A. V., Gumpf, D. J., Lee, R. F., and Garnsey, S. M. 1995. Production of polyclonal antisera to the CP of citrus tristeza virus expressed in Escherichia coli: Application for immunodiagnosis. Phytopathology 85:691-694.

33. Petersen, C. L., and Charles, J. G. 1997. Transmission of grapevine leafroll-associated closteroviruses by Pseudococcus longispinus and $P$. calceolariae. Plant Pathol. 46:509-15.

34. Raine, J., McMullen, R. D., and Forbes, A. R. 1986. Transmission of the agent causing little cherry disease by apply mealybug Phenacoccus aceris and the dodder Cuscuta lupuliformis. Can. J. Plant Pathol. 8:6-11.

35. Rosciglione, B., and Gugerli, P. 1989. Transmission of grapevine leafroll disease and an associated closterovirus to healthy grapevine by the 
mealybug Planococcus ficus. Phytoparasitica 17:63.

36. Rott, M. E., and Jelkmann, W. 2001. Detection and partial characterization of a second closterovirus associated with little cherry disease, Little cherry virus-2. Phytopathology 91:261-267.

37. Saitou, N., and Nei, M. 1987. The neighbor-joining method: A new method for reconstructing phylogenetic trees. Mol. Biol. Evol. 4:406425.

38. Sether, D. M., Ullman, D. E., and Hu, J. S. 1998. Transmission of pineapple mealybug wilt-associated virus by two species of mealybug (Dysmicoccus spp.). Phytopathology 88:1224-1230.

39. Slykhuis, J. T., Yorston, J., Raine, J., McMullen, R. D., and Li, T. S. C. 1980. Current status of little cherry disease in British Columbia. Can. Plant Dis. Surv. 60:37-42.
40. Tanne, E., Ben, D. Y., and Raccah, B. 1989. Transmission of closterolike particles by mealybugs (Pseudococcidae) in Israel. Phytoparasitica 17:63-64.

41. Welsh, M. F., and Cheney, P. W. 1976. Little cherry. Pages 231-237 in: Virus Diseases and Noninfectious Disorders of Stone Fruits in North America. U. S. Dep. Agric. Handb. No. 437, Washington, DC.

42. Yorston, J. M., McMullen, R. D., Slykhuis, J. T., and Welsh, M. F. 1981. Little Cherry Disease in British Columbia. Province of British Columbia Ministry of Agriculture and Food, Victoria, B.C.

43. Zhu, H. Y., Ling, K. S., Goszczynski, D. E., McFerson, J. R., and Gonsalves, D. 1998. Nucleotide sequence and genome organization of grapevine leafroll associated virus-2 are similar to beet yellows virus, the closterovirus type member. J. Gen. Virol. 79:1289-1298. 